\title{
The economic optimization of replacement decisions for sows with a stochastic dynamic programming model
}

\author{
R. B. M. Huirne, A. A. Dijkhuizen and G. W. J. Giesen (Department of Farm \\ Management, Wageningen Agricultural University, Hollandseweg 1, $6706 \mathrm{KN}$ \\ Wageningen, Netherlands)
}

Received 17 November 1986; accepted 26 January 1987

\begin{abstract}
A stochastic dynamic programming model was designed to determine the economically optimum replacement decisions for sows. Influences of changes in production and prices on the optimum policy were established. An economic index was calculated to be used as a culling guide for individual sows.

Key words: sows, replacement policy, economics, dynamic programming

Introduction. A management decision that has to be taken very frequently in swine breeding herds is the decision whether to keep or to replace sows. In the Netherlands, on an average $40-50 \%$ of the sows are replaced annually (Kroes \& van Male, 1979; van der Steen, 1984; Arkes et al., 1986). Mostly, sows are culled because of problems with health and fertility on the one hand and insufficient production on the other. Especially in the latter case, culling decisions are based on economic considerations. That means that a sow is not replaced because she is no longer able to produce in a biological sense, but because a replacement gilt is expected to yield more (Dijkhuizen, 1986). Knowledge of the optimum replacement policy and the influence of changes in production and prices on it may support farmers in taking these day-to-day management decisions.
\end{abstract}

Material and methods. The objective in determining the optimum replacement policy is maximizing the present value of net revenues from sows present in the herd and from subsequent replacement gilts over a given planning horizon. This optimization process is carried out by using the stochastic dynamic programming technique, as developed before in dairy cattle (van Arendonk, 1985).

In the model the decision whether to replace a sow is considered at the time of weaning. Sows are described in terms of parity number and litter size in the previous (maximum) three parities. Parity number varies between 1 and 15 . Litter size is calculated as the number of piglets born alive. Variation in piglet production for sows present in the herd as well as for replacement gilts is taken into account. The risk that a high-producing sow may have a low future piglet production is accounted for.

After a sow's optimum lifespan has been determined, the model calculates the total extra profit to be expected from keeping her until that optimum, compared with 
immediate replacement, taking into account the risk of premature disposal of retained sows. This total extra profit is called retention pay-off (RPO). The RPO is an economic index, which makes it possible to rank sows on future profitability: the higher the RPO, the more valuable the sow. A value below zero means that replacement is the more profitable choice.

The calculations are based on Dutch values for feeder pig sales, slaughter value of culled sows, feed cost, cost of replacement gilts, probability of involuntary disposal and financial losses associated with involuntary disposal of sows. All data can easily be adjusted to represent more precisely a specific herd or a different region of the world.

Results. Given the probabilities of involuntary replacement, the optimum replacement decisions result in an optimum average herd life of 3.43 parities. Culling for insufficient production (voluntary replacement) then accounts for $14 \%$ of the total. Changes in the price of replacement gilts or in slaughter value of culled sows have a significant effect on the optimum replacement policy. The smaller the difference between these two prices, the higher the voluntary replacement rate. Reducing the involuntary disposal is more profitable when part of this reduction is used for increasing voluntary replacement, instead of for increasing the average herd life of the sows only.

The average annual income per sow turns out to be Dfl. 234, and depends to a great extent on feeder pig sales and feed cost. Changes in these two factors, however, do not greatly affect the optimum replacement policy. A compensation then does occur, as the expected income of both the sows present in the herd and the replacement gilts is affected.

In Table 1 the RPO index is presented, calculated at the average time of conception in the herd, and for average producing sows only. As shown in Table 1, the RPO is highest for young sows. At the end of parity 10 the RPO falls below zero. The economic optimum herd life for sows of average productive capacity, therefore, turns out to be 10 parities. The calculated RPO values also represent the maximum amount that could be spent in trying to keep a sow in case of reproductive failure or health problems. The results obtained agree to a great extent with those published by Bisperink (1979) and Dijkhuizen (1986).

Final remarks. The stochastic dynamic programming model will be extended by including variation in other reproduction traits, like heat detection and conception rate. Moreover, it is the intention to use the model in an expert system, which will be developed to support farmers in controlling the economic profitability of individual swine breeding herds.

Table 1. Retention pay-off (RPO) for average producing sows in the parities 1 to 10 .

\begin{tabular}{lrrrrrrrrrr}
\hline Parity & 1 & 2 & 3 & 4 & 5 & 6 & 7 & 8 & 9 & 10 \\
RPO (Dfl.) & 224 & 222 & 187 & 132 & 88 & 55 & 32 & 19 & 8 & - \\
\hline
\end{tabular}


Acknowledgements. The authors are indebted to Th. H. B. Hendriks and H. A. M. van der Steen for their useful advice in developing the model.

\section{References}

Arendonk, J. A. M. van, 1985. Studies on the replacement policies in dairy cattle. Doctoral thesis, Wageningen Agricultural University, Wageningen.

Arkes, J. G., W. H. M. Baltussen, G. J. A. Ogink \& J. Schneider, 1986. Results on swine breeding herds in 1985. Swine Extension Service, Rosmalen and Institute of Agricultural Economics, The Hague (in Dutch).

Bisperink, H. J., 1979. Productivity and profitability of sows. Research report No 3.90, Institute of Agricultural Economics, The Hague (in Dutch).

Dijkhuizen, A. A., 1986. PorkCHOP: an interactive computer model dealing with sow replacement economics. Tijdschrift voor Diergeneeskunde 21: 1055-1063 (in Dutch, English summary).

Kroes, Y. \& J. P. van Male, 1979. Reproductive lifetime of sows in relation to economy of production. Livestock Production Science 6: 179-183.

Steen, H. A. M. van der, 1984. Prediction of future value of sow productivity. Proceedings E.A.A.P., The Hague.

This synopsis is based on an undergraduate thesis entitled 'Een stochastisch dynamisch programmeringsmodel ter ondersteuning van de varkenshouder bij het nemen van de vervangingsbeslissing bij zeugen' by $R$. B. M. Huirne, Departments of Farm Management and Mathematics, Wageningen Agricultural University, Wageningen, 1986. 96 pp., 15 figs., 17 tables, 43 refs., 14 appendices. Dutch.

Available as paper copy (order R070P, $f 20$ including postage) or microfiche (order R070M, f 12.50 including postage) at: NARD, clo Pudoc, P.O. Box 4, 6700 AA Wageningen, Netherlands (telex 45015 blhwg). 